\title{
Peningkatan Proses dan Hasil Belajar Mata Pelajaran Matematika Materi Bangun Datar Menggunakan Model Pembelajaran Discovery Learning (DL)
}

\author{
Yehuda Puja Nugroho ${ }^{* 1}$, Nyoto Harjono ${ }^{2}$ \\ 1,2 Universitas Kristen Satya Wacana
}

\section{A R T I C L E I N F O \\ Article history: \\ Received 19 February \\ 2019 \\ Received in revised form \\ 30 March 2019 \\ Accepted 10April 2019 \\ Available online 21 May 2019}

\section{Kata Kunci:}

Proses, Hasil Belajar,

Matematika Bangun Datar,

Discovery Learning.

Keywords:

Process, Learning

Outcomes, Flat

Mathematics, Discovery

Learning.

\begin{abstract}
A B S T R A K
Artikel ini adalah hasil penelitian tindakan kelas (PTK). Bertujuan untuk memperbaiki proses dan hasil belajar mata pelajaran Matematika siswa kelas 4 SD Marsudirini 78 Salatiga melalui sebuah model pembelajaran Discovery Learning. Mata pelajaran Matematika khususnya materi bangun datar memiliki hasil belajar yang kurang maksimal, demikian pula dengan proses belajar siswa dan kinerja guru yang memperoleh skor rendah dalam pengamatan pra silus. Hal itu terlihat dari perolehan aktivitas guru pra siklus yang memperoleh presentase $67 \%$ dan aktivitas siswa pra siklus yang memperoleh $45 \%$ sehingga presentase ketuntasan hasil belajar pra siklus yaitu $35,5 \%$. simpulan hasil penelitianya adalah penerapan model $\mathrm{DL}$ dapat meningkatkan proses dan hasil belajar Matematika khususnya materi bangun datar. Terbukti presentase ketercapaian aktivitas guru siklus 1 yaitu $66,5 \%$ dan aktivitas siswa $76 \%$ kemudian meningkat pada siklus 2 dengan ketercapaian aktivitas guru $76,5 \%$ dan aktivitas siswa $83 \%$. Keberhasilan hasil belajar dilihat dari presentase ketuntasan siklus 1 dan siklus 2 yaitu 72,7\% meningkat menuju 84\%.
\end{abstract}

A B S T R A C T

This article is the result of classroom action research (CAR). Aiming to improve the learning process and results of Mathematics 4 grade students at SD Marsudirini 78 Salatiga through a Discovery Learning learning model. Mathematics subjects especially flat-build material have less than optimal learning outcomes, as well as student learning processes and teacher performance that get low scores in the pre-silus observation. This can be seen from the acquisition of pre-cycle teacher activities which obtained a percentage of $67 \%$ and pre-cycle student activities that gained $45 \%$ so that the percentage of completeness of the pre-cycle learning outcomes was $35.5 \%$. conclusions of the research results are that the application of the DL model can improve Mathematics learning processes and results, especially flat-build material. It was proven that the percentage of achievement of teacher activity in cycle 1 was $66.5 \%$ and student activities $76 \%$ then increased in cycle 2 with the achievement of teacher activities $76.5 \%$ and student activities $83 \%$. The success of learning outcomes is seen from the percentage of completeness in cycle 1 and cycle 2, which is $72.7 \%$, increasing towards $84 \%$. 


\section{Pendahuluan}

Pendidikan adalah usaha sadar dan terencana untuk mewujudkan suasana belajar dalam proses pembelajaran agar peserta didik secara aktif mengembangkan potensi dirinya. Pendidikan memiliki nilai yang sangat penting dalam pembelajaran, maka dari itu tujuan pendidikan tidak lepas dari proses pembelajaran. Seperti yang dikemukakan Hamalik (2010:80), bahwa tujuan pendidikan memberikan pedoman atau petunjuk kepada guru dalam rangka memilih dan menentukan metode mengajar atau menyediakan linkungan belajar bagi siswa. Guru berperan menciptakan proses pembelajaran yang aktif dan menyenangkan. Salah satu cara yang dilakukan oleh guru untuk meningkatkan proses pembelajaran adalah dengan menentukan pendekatan, model, atau metode pada pembelajaran yang dilaksanakannya. Dapat dituliskan bahwa berhasil tidaknya pencapaiaan tujuan pembelajaran tergantung kepada proses belajar yang dialami oleh siswa..

Salah satu pembelajaran yang sering mengalami kegagalan dalam menperoleh proses dan hasil belajar yang baik adalah Matematika. Pembelajaran matematika merupakan pembelajaran yang memungkinkan siswa untuk dapat memecahkan suatu masalah yang dihadapi. Lampiran peraturan menteri pendidikan nasional tahun 2006 mengatakan bahwa mata pelajaran matematika perlu diberikan kepada peserta didik mulai dari sekolah dasar supaya siswa mampu berpikir secara logis, sistematis, kritis, dan kreatif. Pembelajaran matematika ini juga diharapkan mampu menjadi sarana dalam pemecahan masalah.

Menurut ibrahim (2012:2) matematika bangun datar adalah ilmu deduktif yang harus dibuktikan kebenaranya karena matematika merupakan ilmu yang abstrak maka untuk mempelajarinya tidak hanya melalui observasi dan coba - coba tetapi harus dilakukan percobaan untuk membuktikanya. Lebih lanjut matematika merupakan serangkaian proses kegiatan dalam mempelajari konsep matematika dan struktur matematika yang melibatkan guru matematika dan siswanya dalam usaha mencapai kompetensi dasar yang telah ditetapkan. Dengan demikian guru sebagai dinamisator dan fasilitator perlu memperhatikan daya imajinasi dan rasa ingin tahu siswa, sehingga siswa perlu dibiasakan untuk diberi kesempatan bertanya dan berpendapat.

Hal ini terbukti dengan hasil pengamatan kegiatan pra siklus pembelajaran Matematika khususnya materi bangun datar, yang membahas tentang luas dan keliling persegi, persegi panjang, dan segitiga. Materi itulah yang diangap sulit oleh siswa, terbukti dengan penelitiaan yang dilakukan Muhamad Sholeh (2018) KD Matematika konsep luas dan keliling bangun datar sangat sulit dipahami siswa. hal ini serupa dengan penelitian yang saya lakukan pada siswa kelas 4 SD Marsudirini 78 Salatiga semester 2 tahun pelajaran 2018/2019. Hal ini dapat dilihat dari hasil observasi di dalam kelas, wawancara guru kelas, dan hasil belajar yang masih rendah. Pada hasil ulangan harian KD 3.9 dan 4.9 dengan kriteri ketuntasan minimal (KKM) 75, siswa yang mendapatkan nilai di bawah 75 terdapat 25 siswa atau dipresentasekan 55\% dan siswa yang mendapat nilai di atas 75 sebanyak 20 siswa atau dipresentasekan $45 \%$. Hal ini dapat diperkuat dengan wawancara bersama guru kelas yang mengungapkan tentang siswa yang pasif dalam pembelajaran dan jarang bertukar pikiran atau berdiskusi dengan teman dalam kelompok belajarnya.

Oleh karena itu diperlukan sebuah inovasi dalam pembelajaran yang diterapkan dikelas salah satunya dengan menerapka berbagai model pembelajaran. Salah satu model pembelajaran yang bias diterapkan yaitu Discovery Learning (DL). Model DL akan menjadikan pengetahuan yang diperoleh siswa akan lama diingat, konsep-konsep jadi lebih mudah diterapkan pada situasi baru dan meningkatkan penalaran siswa menurut Nurdin (2016:212). Sedangkan Menurut (Anitah, 2009) belajar penemuan atau DL merupakan suatu pembelajaran yang melibatkan peserta didik dalam pemecahan masalah untuk pengembangan pengetahuan dan keterampilan. Tiga ciri utama dari belajar menemukan DL yaitu : (1) mengeksplorasi dan memecahkan masalah untuk menciptakan, menggabungkan dan menggeneralisasikan pengetahuan; (2) berpusat pada siswa (3) kegiatan untuk menggabungkan pengetahuan baru dan pengetahuan yang sudah ada. Model DL dapat meningkatkan aktivitas dan prestasi belajar siswa.

Berdasarkan pendapat para ahli dapat disimpulkan bahwa model DL merupakan proses pembelajaran yang melibatkan siswa untuk mengorganisasikan sendiri materi pembelajaran dengan penekanan pada penemuan konsep atau prinsip yang sebelumnya tidak diketahui siswa. Melalui penemuan, peserta didik belajar secara intensif dengan mengikuti metode investigasi ilmiah dan cenderung meminta siswa untuk melakukan observasi, eksperimen, atau tindakan ilmiah hingga mendapatkan kesimpulan dari hasil tindakan ilmiah.

Penelitian dengan menggunakan Model Discovery Learning sebelumnya telah dilakukan oleh Meiria Sylvi Astuti dalam Penelitian Tindakan Kelas yang berjudul " Peningkatan Keterampilan Bertanya Dan Hasil Belajar Siswa Kelas 2 SDN Slungkep 03 Menggunakan Model Discovery Learning”. Peningkatan keterampilan bertanya siswa siklus I dari kategori sedang menjadi kategori tinggi diakhir siklus II sebesar 19,22\%. Sementara Jumlah siswa yang tuntas untuk muatan Bahasa Indonesia siklus I mencapai $73,33 \%$ menjadi 86,67\% diakhir siklus II. Jumlah siswa yang tuntas untuk muatan PPKn dari siklus I sebesar $66,67 \%$ menjadi 
$86,67 \%$ diakhir siklus II. Sementara jumlah siswa tuntas untuk muatan Matematika, dari siklus I sebesar 46,67\% menjadi 80,00\% diakhir siklus II. Ketuntasan hasil belajar siswa tersebut mampu mencapai kategori tinggi rata- rata sebesar 18,19\%-33,33\%. (Meiria, 2015)

Penelitian kedua yang relevan dengan proposal yang penulis susun adalah penelitian dari Vivi Novita Sari dalam Penelitian Tindakan Kelas yang berjudul "Penerapan Model Discovery Learning Sebagai Upaya Meningkatkan Kemampuan berhitung Siswa Kelas IV Sekolah Dasar". Pada penelitiannya hasil evaluasi siklus I mencapai $100 \%$ dengan nilai ketercapaian adalah $88,94 \%$. Sedangkan pelaksanaan pembelajaran siklus II juga telah mencapai $100 \%$ dengan nilai ketercapaian 91,045. Ketuntasan mencapai 73,07\% pada siklus I dan 84,61\% pada siklus II. (Sari, 2014)

Berdasarkan persoalan yang telah ditemukan maka dapat dibuat dua pertanyaan masalah sebagai berikut : 1. Bagaimana penerapan model pembelajaran Discovery Learning dalam meningkatan proses pembelajaran mata pelajaran matematika materi bangun datar pada siswa kelas 4 SD FX. Marsudirini 78 Kota Salatiga Semester 2 tahun 2018 - 2019, 2. Apakah peningkatan proses melalui penerapan model pembelajaran Discovery Learning dapat memperbaiki hasil belajar siswa pada mata pelajaran matematika materi bangun datar pada siswa kelas 4 SD FX. Marsudirini 78 Salatiga Semester 2 tahun 2018 - 2019

\section{Metode}

Penelitian dilakukan di SD FX Masudirini 78 Salatiga salah satu SD Swasta Khatholik yang terletak di kelurahan Salatiga, Kecamatan Sidorejo, Kota Salatiga. Letak sekolah berada Pusat kota Salatiga JL. Margosari Sidorejo Salatiga. Sekolah berdekatan dengan SDN Salatiga 3 dan SDN Salatiga 9. Lingkungan yang ada di sekolah cukup nyaman untuk proses belajar mengajar. Penelitian dilakukan pada semester II, Tahun Pelajaran 2018/2019 di SD FX Marsudirini 78 Salatiga. Penelitian tindakan kelas siklus I dilaksanakan sebanyak 3 kali pertemuan, 2 kali tatap muka dan 1 ambil data yang dimulai pada minggu pertama pada pertengahan bulan Februari tahun 2019 sampai akhir bulan Februari tahun 2019. Adapun Subjek penelitian ini adalah siswa kelas 4 SD FX Marsudirini 78 Salatiga tahun pelajaran 2018/2019. Siswa kelas 4 SD Marsudirini 78 Salatiga berjumlah 45 siswa terdiri dari 21siswa laki-laki dan 24 siswa perempuan dengan karateristik siswa yang bervariasi dan rata-rata umur 11 tahun dan ada 5 anak yang 12 tahun.

Menurut Kemmis dan Mc Taggart dalam (Mulyasa, 2011) yang membagi prosedur penelitian tindakan dalam tiga tahap kegiatan pada satu putaran (siklus) yaitu perencanaan, pelaksanaan tindakan dan observasi dan refleksi dalam suatu spiral yang saling terkait. Model spiral ini merupakan model siklus berulang berkelanjutan, dengan harapan pada setiap tindakan menunjukkan peningkatan sesuai perubahan dan perbaikan yang ingin dicapai. Sebagai contoh hasil refleksi pada siklus 1 digunakan untuk meperbaiki pembelajaran pada silus II. Apabila pencapaian aktivitas belajar meningkat sebesar 15\% dan ketuntasan hasil belajar diatas KKM (>75) meningkat sebesar 80\%. Maka tidak perlu perbaikan kembali dalam penerapan model pembelajaran DL

Teknik analisis data dalam penelitian ini dimaksudkan untuk mengetahui peningkatan hasil belajar mata pelajaran Matematika materi bangun datar kelas 4 SD Marsudirini 78 Salatiga. Selain itu instrument pengumpulan data juga dimaksudkan untuk mengetahui peningkatan aktivitas guru dan siswa selama tindakan pembelajaran menggunakan model pembelajaran DL. Teknik data untuk mengetahui aktivitas guru dan siswa mengunakan teknik data analisis Diskriftif, dan hasil belajar siswa mengunakan teknik anlaisis diskrftif Komporatif dengan menghitung presentase ketuntasan belajar mata pelajaran Matematika Khususnya materi bangun datar.

Peneltian ini mengunakan tes sebagai alat pengumpulan data untuk variabel hasil belajar mata pelajaran matematika khususnya materi bangun datar. Dalam variabel proses pembelajaran peneliti mengunakan lembar observasi. Alat untuk mengumpulkan data khususnya tes harus diuji Validitaskan. Pada uji validitas soal siklus I, memiliki instrumen soal valid koefesien corrected item to totall correlation $>0,349$ dan pada siklus II koefesien corrected item to totall correlation $>0,329$. Pada uji reliabilitas setelah dikurangi item yang tidak valid pada siklus 1 cronbach alpha Sebesar 0,76 dari 30 item yang diuji, sedangkan pada siklus II cronbach alpha Sebesar 0,86 dari 30 item yang diuji. Data yang diperoleh dari hasil pelaksanaan PTK adalah data kuantitatif. Penelitian ini mengunakan analisis kuantitatif dengan statistik deskriptif. Sedangkan hasil belajar mengunakan teknik komporatif untuk membandingkan hasil belajar dari pra siklus, sklus 1 , dan siklus 2 .

\section{Hasil dan Pembahasan}

Berdasarkan hasil pengamatan yang peneliti buat pada kondisi awal, diperoleh data bahwa pada saat diberikan tugas oleh peneliti hanya ada 45\% (20 peserta didik) menyelesaikan tugas tepat waktu dan sesuai dengan prosedur yang ditetapkan guru. Sedangkan 55\% (25 peserta didik) meskipun tepat dalam waktu 
penyelesaian tugas, namun tugas yang diberikan tidak dikerjakan sendiri. Mereka mengerjakan di sekolah atau mencontoh pekerjaan teman yang lain, selain itu keaktifan siswa dalam mengikuti pembelajaran sangat kurang. Hal itu dapat dilihat dari menjawab pertanyaan guru dan bertanya kepada temanya. Aktivitas guru memiliki presentase $67 \%$ dan siswa $45 \%$. Hal itu yang membuat hasil belajar siswa kurang baik. Karena presentase ketuntasanya yaitu $35,5 \%$ dengan frekuensi 16 siswa dari 45 siswa.

Pelaksanaan siklus 1 ini dilaksanakan dalam 3 pertemuaan yaitu pertemuan I, pertemuan 2, dan pertemuan 3. Pelaksanaan siklus 1 dilaksanakan pada tanggal 4, 6, dan 8 Februari 2019. Hal - hal yang dilakukan pada siklus 1 adalah perencanaan antara lain : rencana pelaksanaan pembelajaran, (RPP) siklus I, lembar observasi aktivitas siswa dalam proses pembelajaran. Lembar observasi aktivitas guru pada saat mengajar menerapkan model pembelajaran discovery learning.

Berdasarkan pengamatan proses pembelajaran aktivitas siswa dan aktivitas guru pada proses pembelajaran matematika mengunakan model pembelajaran DL. Memperoleh hasil sebagai berikut :

Tabel 1. Hasil Observasi Kinerja Guru Siklus I

\begin{tabular}{cllll}
\hline No & Tahapan Kegiatan & \multicolumn{1}{c}{ Aspek Yang diamati } & Hasil Pertemuan 1 & $\begin{array}{c}\text { Hasil } \\
\text { Pertemuan 2 }\end{array}$ \\
\hline 1 & Kegiatan Awal & $1-5$ & 14 & 18 \\
2 & Kegiatan inti & $6-15$ & 30 & 38 \\
$3 \quad$ Kegiatan Akhir & $16-20$ & 15 & 18 \\
Total Skor & & 59 & 74 \\
Kriteria & & Cukup Baik & Baik \\
Skor Maksimal & & 100 & \\
Rata- rata Skor Siklus 1 & \multicolumn{2}{c}{ Sumber: Hasil Penelitian, diolah (2019) }
\end{tabular}

Berdasarkan Tabel 1 dapat dilihat aktivitas guru pada pertemuaan pertama dan kedua mengalami peningkatan. Pada perolehan pertama memperoleh skor 59 dan pada pertemuan kedua memperoleh skor 74. Sehingga diperoleh rata-rata skor aktivitas guru siklus 1 sebesar 66,5 . Selanjutnya adalah aktivitas siswa yang meliputi kegiatan-kegiatan yang dilakukan siswa selama proses pembelajaran. Aspek pengamatan aktivitas siswa terdiri dari 15 aspek yang diamati, dan memiliki rentang skor 1-4. Berikut akan disajikan pengamatan aktivitas siswa Siklus I:

Tabel 2. Hasil Observasi Aktivitas Siswa Siklus 1

\begin{tabular}{|c|c|c|c|c|}
\hline No & Tahapan Kegiatan & Aspek Yang diamati & Hasil Pertemuan 1 & $\begin{array}{c}\text { Hasil } \\
\text { Pertemuan } 2\end{array}$ \\
\hline 1 & Kegiatan Awal & $1-3$ & 9 & 11 \\
\hline 2 & Kegiatan inti & $4-12$ & 27 & 30 \\
\hline 3 & Kegiatan Akhir & $13-15$ & 9 & 10 \\
\hline \multicolumn{3}{|c|}{ Total Skor } & 45 & 51 \\
\hline \multicolumn{3}{|c|}{ Kriteria } & Baik & Sangat Baik \\
\hline \multicolumn{3}{|c|}{ Skor Maksimal } & 60 & \\
\hline \multicolumn{3}{|c|}{ Rata- rata Skor Siklus 1} & 76 & \\
\hline
\end{tabular}

Berdasarkan Tabel 2 dapat dilihat aktivitas siswa pada pertemuan pertama dan kedua mengalami peningkatan. Pada perolehan pertama memperoleh skor 45 dengan nilai maksimal skor yaitu 60 sehingga memiliki kriteria baik. Pada pertemuan kedua memperoleh skor 51 dengan maksimal 60 sehinga memiliki kriterria sangat baik. Dengan rata - rata skor aktivitas siswa pada siklus 1 sebesar 76.

Setelah mengetahui hasil dari proses belajar aktivitas guru dan siswa selanjutnya akan diperlihatkan hasil belajar mata pelajaran Matematika materi bangun datar melalui ketuntasan belajar yang disediakan melalui tabel berikut:

Tabel 3. Ketuntasan Belajar Siklus 1

\begin{tabular}{ccccc}
\hline No. & $\begin{array}{c}\text { Ketuntasan } \\
\text { Belajar }\end{array}$ & KKM & Frekuensi & Jumlah Siswa \\
\hline 1 & Tuntas & 75 & 31 & $70,3 \%$ \\
\hline
\end{tabular}




\begin{tabular}{|c|c|c|c|c|}
\hline 2 & Belum Tuntas & 75 & 13 & $29,7 \%$ \\
\hline & Jumlah & & 44 & $100 \%$ \\
\hline
\end{tabular}

Sumber: Hasil Penelitian diolah (2019)

Dari Tabel 3 diatas dapat dikatakan hasil penelitian hasil belajar mata pelajaran Matematika materi bangun datar. Dilihat dari ketuntasan belajar dari 44 siswa yang mengikuti tes terdapat 31 siswa yang dinyatakan tuntas dan 13 siswa belum tuntas apabila dipresentasekan 70,3\% siswa tuntas dalam pembelajaran Matematika materi bangun datar. Sehingga hasil pencapaiaan tersebut belum memenuhi indikator hasil pencapaiaan $80 \%$ dari 44 siswa tuntas, maka perlu dilakukan tindakan kembali pada siklus II. Siklus II dilakukan untuk memperbaiki kekurangan dari siklus I. Siklus II juga dilaksanakan selam 3 pertemuaan dilakukan pada tanggal 11,13, 15 Februari 2019. Hal - hal yang dilakukan pada kegiatan siklus II adalah perencanaan antara lain: RPP yang dibuat mengunakan sintaks Discovery Learning, lembar observasi aktivitas siswa dan aktivitas guru.

Berdasarkan pengamatan terhadap proses pembelajaran mata pelajaran matematika materi bangun datar mengunakan model pembelajaran DL Pada siswa kelas 4 SD Marsudirini 78 Salatiga memperoleh aktivitas guru dan aktivitas siswa. aktivitas guru adalah pelaksanaan sintaks model pembelajaran Discovery learning. Lembar pengamatan aktivitas guru terdiri dari 20 Aspek yang diamati dengan rentang skor 1-4. Disajikan pada Tabel 4 berikut ini :

Tabel 4. Hasil Observasi Kinerja Guru Siklus II

\begin{tabular}{|c|c|c|c|c|}
\hline No & Tahapan Kegiatan & Aspek Yang diamati & Hasil Pertemuan 1 & $\begin{array}{c}\text { Hasil } \\
\text { Pertemuan } 2\end{array}$ \\
\hline 1 & Kegiatan Awal & $1-5$ & 15 & 18 \\
\hline 2 & Kegiatan inti & $6-15$ & 43 & 45 \\
\hline 3 & Kegiatan Akhir & $16-20$ & 14 & 18 \\
\hline \multicolumn{3}{|c|}{ Total Skor } & 72 & 81 \\
\hline \multicolumn{3}{|c|}{ Kriteria } & Baik & Baik \\
\hline \multicolumn{3}{|c|}{ Skor Maksimal } & 100 & \\
\hline \multicolumn{3}{|c|}{ Rata- rata Skor Siklus 1} & 76,5 & \\
\hline
\end{tabular}

Sumber : Hasil Penelitian , diolah(2019)

Dari Tabel 4 dapat dilihat hasil observasi kinerja guru pada pertemuaan pertama siklus II mengalami peningkatan. Pada pertemuan pertama memperoleh skor 72 dengan skor maksimal 100 sehinga memiliki kriteria baik. Pada pertemuan kedua meningkat dengan memperoleh skor 81 dengan skor maksimal 100 sehinga memiliki kriteria baik. Walaupun memiliki kriteria yang sama baik tetapi meiliki hasil skor yang berbeda dan meningkat. Hal itu berbeda dengan hasil observasi aktivitas siswa yang disajikan melalui Tabel berikut ini

Tabel 5. Hasil Observasi Aktivitas Siswa Siklus II

\begin{tabular}{|c|c|c|c|c|}
\hline No & Tahapan Kegiatan & Aspek Yang diamati & Hasil Pertemuan 1 & $\begin{array}{c}\text { Hasil } \\
\text { Pertemuan } 2\end{array}$ \\
\hline 1 & Kegiatan Awal & $1-3$ & 9 & 11 \\
\hline 2 & Kegiatan inti & $4-12$ & 32 & 34 \\
\hline 3 & Kegiatan Akhir & $13-15$ & 10 & 10 \\
\hline \multicolumn{3}{|c|}{ Total Skor } & 51 & 55 \\
\hline \multicolumn{3}{|c|}{ Kriteria } & Sangat Baik & Sangat Baik \\
\hline \multicolumn{3}{|c|}{ Skor Maksimal } & 60 & \\
\hline \multicolumn{3}{|c|}{ Rata- rata Skor Siklus II } & 86 & \\
\hline
\end{tabular}

Berdasarkan Tabel 5 diatas dapat dilihat bahwa siklus 2 setiap pertemuanya memilki hasil yang baik dan meningkat. Pada pertemuan pertama memperoleh skor 51 denan skor maksimal 60 sehingga memiliki kriteria sangat baik sedangkan pada pertemuan kedua meningkat dengan memperoleh skor 55 dengan skor maksimal 60 sehinga memiliki kriteria sangat baik. Rata rata skor aktivitas siklus II adalah 86. 
Selain penelitian proses peneliti juga melaksanakan tes untuk mengukur hasil belajar siswa keas 4 SD Marsudirini 78 Salatiga. Berikut akan diperlihatkan hasil ketuntasan belajar siswa saat mengerjakan mata pelajajaran Matematika materi bangun datar :

Tabel 6. Ketuntasan Belajar Siklus II

\begin{tabular}{ccccc}
\hline \multirow{2}{*}{ No. } & Ketuntasan & \multirow{2}{*}{ Nilai } & \multicolumn{2}{c}{ Jumlah Siswa } \\
& Belajar & 75 & 37 & Frekentase \\
\hline 1 & Tuntas & 75 & 7 & $83,4 \%$ \\
2 & Belum Tuntas & & 44 & $16,6 \%$ \\
& Jumlah & & $100 \%$ \\
\hline
\end{tabular}

Berdasarkan hasil observasi kegiatan guru pada siklus II pertemuan pertama diperoleh skor Sumber : Hasil Penelitian diolah, (2019). Dari Tabel diatas dapat dikatakan hasil penelitian hasil belajar mata pelajaran Matematika materi bangun datar. Dilihat dari ketuntasan belajar dari 44 siswa yang mengikuti tes terdapat 37 siswa yang dinyatakan tuntas dan 7 siswa belum tuntas apabila dipresentasekan $83,4 \%$ siswa tuntas dalam pembelajaran Matematika materi bangun datar. Sehingga hasil pencapaiaan tersebut telah memenuhi dan melampaui indikator hasil pencapaiaan $80 \%$ dari 44 siswa tuntas, maka dapat dikatakan penerapan model pembelajaran DL berhasil meningkatkan proses dan hasi belajar siswa

a. Aktivitas Belajar

Pada bagian ini akan dibahas peningkatan proses belajar peserta didik dari hasil obsevasi pada kondisi awal, siklus I dan siklus 2, serta peningkatan hasil belajar peserta didik dalam proses pembelajaran dari kondisi awal, siklus I, dan siklus 2. Berikut akan disajikan hasil observasi kinerja guru dan hasil observasi aktivitas siswa dari setiap tindakan penelitianya :

Tabel 7 Perbandingan Proses Belajar Pra Siklus, Siklus 1, dan Siklus 2

\begin{tabular}{cccccccc}
\hline No & \multirow{2}{*}{ Tindakan } & \multicolumn{2}{c}{ Pra Siklus } & \multicolumn{2}{c}{ Siklus I } & \multicolumn{2}{c}{ Siklus II } \\
& & skor & Kriteria & Skor & Kriteria & Skor & Kriteria \\
\hline 1 & Aktivitas Guru & 60 & Cukup & 66,5 & Cukup Baik & 76,5 & Baik \\
2 & Aktivitas Siswa & 57 & Siswa Pasif & 76 & Baik & 86,5 & Sangat baik \\
\hline
\end{tabular}

Berdasarkan Tebel 7 dapat diketahui bahwa terjadi peningkatan aktivitas kinerja guru dan aktivitas kineja siswa dari pra siklus, siklus 1 , siklus II. Saat tindakan pra siklus kriteria dari proses belajar hanya cukup dan siswa pasif. Tetapi meningkat di siklus I Dengan jumllah skor yang cukup baik yaitu 66,5 dan aktivitas siswanya meningkat baik menjadi 76. Hal itu terjadi karena guru mendesain pembelajaran mengunakan model pembelajaran discovery learning. Hal itu dirasa kurang untuk meningkatkan proses aktivitas guru dan siswa maka perlu adanya siklus II yang memiliki hasil 76,5 pada aktivitas guru degan kriteria baik. Hal itu seiring meningkat jdengan aktivitas siswa yang memiliki skor 86,5 dengan kriteria sangat baik.

b. Hasil Belajar

Hasil belajar diperoleh dari tes evaluasi setiap tindakanya dari tindakan pra siklus, siklus I, siklus II. Hal itu dapat dilihat dari jumllah siswa yang memiliki nilai diatas KKM atau tuntas dalam pembelajaran Matematika materi bangun datar. Berikut akan ditampilkan ketuntasan hasil belajar Matematika materi bangun datar

Tabel 8. Perbandigan ketuntasan dan Hasil belajar Mata Pelajaran Matematika Materi Bangun Datar

\begin{tabular}{clcccccc}
\hline \multirow{2}{*}{ No } & \multirow{2}{*}{ Ketuntasan } & \multicolumn{2}{c}{ Kondisi Awal } & \multicolumn{2}{c}{ Siklus I } & \multicolumn{2}{c}{ Siklus II } \\
& & Jumlah & $\%$ & Jumlah & $\%$ & Jumlah & $\%$ \\
\hline 1 & Tuntas & 16 & $35,5 \%$ & 32 & $72,7 \%$ & 37 & $84 \%$ \\
2 & Belum Tuntas & 29 & $65,7 \%$ & 13 & $29,3 \%$ & 7 & $16 \%$ \\
\hline
\end{tabular}

Setelah melihat Tabel tentang perbandingan ketuntasan belajar mata pelajaran Matamatika khususnya materi bangun datar dapat diketahui bahwa terdapat peningkatan hasil belajar dari kondisi awal, siklus I, dan siklus 2. Pada kondisi awal atau sebelum pelaksanaan tindakan, peserta didik yang tuntas atau telah mencapai Kriteria Ketuntasan Minimal $(\mathrm{KKM}=75)$ hanya berjumlah 16 anak dengan 
persentase 36,3\% sementara peserta didik yang belum tuntas berjumlah 29 anak dengan persentase $65,7 \%$. Selanjutnya setelah pelaksanaan tindakan siklus I terlihat peningkatan jumlah peserta didik yang tuntas sebanyak 32 anak dengan persentase peserta didik tuntas 72,7\%, sementara 13 anak lainnya masih memperoleh nilai di bawah KKM dengan persentase 29,3\%,. Meningkat kembali pada siklus II dengan jumllah siswa tuntas 37 atau $84 \%$ dan siswa tidak tuntas hanya 7 orang atau $16 \%$.

Berdasarkan hasil observasi proses belajar peserta didik pada mata pelajaran Matematika khususnya materi bangun datar dengan KD 3.9 dan KD 4.9 tentang menentukan luas dan keliling beserta sifat - sifat nya tentang bangun datar persegi, persegi panjang, dan Segitiga . Peserta didik kurang antusias dalam mengikuti proses pembelajaran, bahkan tingkat aktivitas peserta didik rendah, hal itu seimbang dengan hasil belajar siswa yang dilihat dari jumllah siswa tuntas dalam mengikuti pembelajaran Matematika khususnya materi bangun datar. Berdasarkan kondisi yang demikian penulis merasa perlu adanya tindakan perbaikan pembelajaran untuk meningkatkan proses dan hasil belajar siswa Mata pelajaran Matematika SD Marsudirini 78 Salatiga dengan mengunakan model pembelajaran discovery learning.

Setelah melaksanakan pemelajaran matematika mengunakan model DL. Dan dilaksanakan secara keseluruhan baik siklus I dan siklus II. Siswa terbukti aktif dalam proses pembelajaran. Meningatnya proses belajar siswa seiring juga meningkat dengan hasil belajar siswa mata pelajaran matematika materi bangun datar terlihat dari tabel ketuntasan belajar siklus I yang memiliki presentase 70,1\%. Hal itu masih kurang dalam indikator keberhasilan yang ditentukan peneliti yaitu $80 \%$. sehinga perlu dilakukan tindakan berikutnya yaitu siklus II. Maka diadakan refleksi sebagai perbaikan pada siklus II. Pada pembelajaran siklus I hal - hal yang perlu diperbaiki yaitu pada langkah memanajemen peserta didik untuk belajar, siswa kurang berperan aktif atau pasif dalam pembelajaran dan guru jarang memberikan ruang kepada siswa untuk beriskusi dengan temanya. Pada siklus II hasil belajar ketuntasan siswa mencapai 84\% dengan jumllah siswa tuntas sebanyak 37 dari 44 siswa yang mengkuti tes. Hal itu dirasakan penulis bahwa siklus II melampaui target penulis yaitu siswa tuntas sebanyak $80 \%$.

Model DL membuat siswa ikut terlibat dalam mencari pengetahuan dalam proses pembelajaran dalam mencari pengetahuan pada proses belajar mengunakan suatu masalah sehingga menumbuhkan rasa ingin tau siswa, menaktifkan siswa, dan siswa mampu bertukar pikiran dengan teman sekelompoknya. Model pembelajaran DL dapat mengurangi perasaan keminderan dalam pembelajaran kelompok. selain itu model pembelajaran DL juga melatih kerjasama siswa dalam melaksanakan tindakan kelompok.

Dengan menggunakan model pembelajaran discovery learning pada siklus 1 dan siklus 2 dapat meningkatkan proses dan hasil belajar peserta didik terhadap mata pelajaran Matematika materi bangun datar pada SD Marsudirini 78 Salatiga, sehingga peserta didik memperoleh hasil belajar yang baik. Berdasarkan uraian penelitian yang telah disajikan, maka penerapan model pembelajaran discovery learning dalam pembelajaran Matematika khususnya materi bangun datar pada siswa kelas 4 Semester 2 SD Marsudirini 78 Tahun Pelajaran 2018/2019 ini hampir sama dengan penelitian yang dilakukan sebelumnya oleh Firosalia Kristin dalam Penelitian Tindakan Kelas yang berjudul "Analisis Model PembelajaranDiscovery Learning Dalam meningkatkan hasil Belajar Siswa SD”. Pada penelitiannya hasil analisis meta menunjukkan bahwa model Discovery Learning mampu meningkatkan hasil belajar siswa mulai dari yang terendah $9 \%$ sampai yang tertinggi 27\% dengan rata-rata 17,8\%. (Firosalia, 2016)

\section{Simpulan Dan Saran}

Berdasarkan hasil penelitian tindakan kelas yang dilaksanakan pada siklus I dan siklus II dengan menerapkan Pembelajaran Discovery Learning pada siswa kelas 4 di SD Marsudirini 78 Salatiga, menunjukkan adanya peningkatan aktivitas siswa, hasil belajar, dan performansi guru di kelas 4 pada materi sifat-sifat bangun datar. Adapun kesimpulan dari penelitian tersebut sebagai berikut: Mengunakan model pembelajaran DL mempengaruhi hasil belajar mata pelajaran matematika materi bangun datar mengalami peningkatan.

Pembelajaran DL memberikan pengalaman belajar kepada siswa melalui pemecahan masalah kontekstual. Proses pemecahan masalah dilakukan secara kelompok mendorong aktivitas siswa menjadi aktif bertanya, kerjasama siswa dalam membuat atau mengembangkan model pemecahan menjadi lebih baik, siswa berani mempresentasikan hasil kerja, siswa berani mengemukakan pendapat, dan tekun dalam mengerjakan tugas yang diberikan oleh guru. Peningkatan aktivitas siswa dalam pembelajaran dengan menggunakan model pembelajaran discovery learning pada siklus I mencapai $76 \%$ dan siklus II mencapai 83\%. Pembelajaran discovery learning mendorong aktivitas siswa dalam pemecahan masalah. Saat melakukan aktivitas pemecahan masalah, siswa diberi kesempatan menbangun pengetahuannya mengenai sifat-sifat bangun datar dan menghitung luas dan keliling bangun datar dengan strategi 
pemecahan masalah yang tepat.hal tersebut membuat hasil belajar siswa menjadi meningkat, Peningkatan hasil belajar siswa, setelah guru menerapkan pembelajaran Discovery learning dibuktikan dari hasil tes formatif pada siklus I dan siklus II, dengan jumllah siswa yang tuntas pada siklus I yaitu $72,7 \%$ kemudian meningkat pada siklus II menjadi $84 \%$.

Dari berberapa peningkatan tersebut dapat dikatakan bahwa model pembelajaran discovery learning mampu meningkatkan proses aktivitas guru maupun siswa yang membuat hasil belajar menjadi baik dengan nilai yang melampaui KKM pada mata pelajaran Matematika khususnya materi bangun datar persegi, persegi panjang, Segitiga.

Berdasarkan kesimpulan diatas, maka saran untuk hasil setelah dilakukan penelitian ini adalah sebagai berikut : 1) Siswa diharapkan lebih aktif dalam mengikuti proses pembelajaran apapun, dengan model pembelajaran yang berbeda dari Discovery Learning. Dikarenakan apabila siswa aktif dalam proses pembelajaran siswa akan memiliki pengalaman belajar secara langsung dan hasil belajar siswa meningkat. 2) Guru hendaknya guru di Sekolah Dasar menggunakan Pembelajaran yang inovatif dalam pembelajaran matematika khususnya pada materi sifat-sifat bangun datar dan menghitung luas dan keliling bangun datar. Dalam menggunakan Model pembelajaran Inovatif seperti discovery learning, sebaiknya guru menggunakan media/alat peraga yang dekat dengan kehidupan sehari-hari siswa dan mengenalkan konsep matematika yang abstrak melalui benda nyata dan masalah kontekstual, sehingga pembelajaran yang dilakukan menjadi bermakna bagi siswa. Pelaksanaan Pembelajaran discovery learning memerlukan peran guru sebagai fasilitator pembelajaran, oleh sebab itu hendaknya guru memantau aktivitas siswa selama kegiatan belajar berlangsung agar kegiatan pembelajaran berjalan dengan efektif dan meningkatkan hasil belajar siswa.

\section{Daftar Rujukan}

Abdilah. (2018). Pengembangan Modul dengan Menggunakan Model Pembelajaran Discovery Learning untuk Meningkatkan Hasil Belajar,hlm. 37-46

Azwar , Saifudin. (2005) . Metode Penelitian . Jakarta : Pustaka Belajar.

Depdiknas. (2005). Landasan Teori dalam Pengembangan Metode Pengajaran. Materi Pelatihan Terintegrasi Ilmu Pengetahuan Alam. Jakarta: Depdik-nas Dirjen Pendasmen Direktorat Pend. Lanjutan Pertama.

Dimyati dan Mudjiono. 1999. Belajar dan Pembelajaran. Jakarta: Rineka Cipta

Elsa, dkk. (2017). Pengaruh Penggunaan Model Discovery Learning Terhadap Keterampilan Menulis Karangan Argumentasi Siswa Kelas X SMA Negeri 3 Pariaman, hlm. 118-127.

Firdhaus, Ryandi, dkk. (2017). Penggunaan Discovery Learning dengan Media Model Bangun Ruang pada Siswa Kelas V SD, hlm. 207-210.

Hosnan. (2014). Pendekatan Saintifik Dan Kontekstual Dalam Pembelajaran Abad 21. Jakarta: Ghalia Pustaka.

Kemendikbud. (2013). Materi Pelatihan Guru, Implementasi Kurikulum. 2013.Jakarta: Kementerian Pendidikan dan Kebudayaan.

Kemendikbud, (2016). Panduan Teknis Pembelajaran Dan Penilaian Di Sekolah Dasar. Jakarta: Direktorat Pembinaan Sekolah Dasar.

Kusumarani, Ika. (2017). Penerapan Model Discovery Learning untuk Meningkatkan Hasil Belajar Matematika pada Siswa Kelas VIII-G SMP Negeri 1 Salatiga

Marantika, Aryani, dkk. (2015). Pengaruh Metode Discovery Learning Terhadap Kemampuan Pemecahan Masalah Matematika Siswa pada Pembelajaran Matematika di SMP Pelita Palembang, hlm. 161-183.

Mulyasa, E. (2011). Praktik Penelitian Tindakan Kelas. Bandung: Remaja Rosdakarya.

Oemar Hamalik. (2006). Proses Belajar Bandung. Bumi Mengajar. Aksara 
Sari, Ni Made Meita Purnama, dkk. (2017). Pengaruh Model Discovery Learning Terhadap Hasil Belajar Matematika Siswa pada Kelas V di SD, hlm. 1-10.

Subroto, dkk. (2003). Pembelajaran Terpadu. Jakarta: Pusat Penerbitan Universitas Terbuka.

Sudjana, N. (2011). Penilaian Hasil Belajar Mengajar. Bandung: Rosda Karya.

Sugiyono. (2009). Metode Penelitian Pendidikan. Bandung: Alfabeta.

Supriyanto, Bambang. (2014). Penerapan Discovery Learning untuk Meningkatkan Hasil Belajar Siswa Kelas VI B Mata Pelajaran Matematika Pokok Bahasan Keliling dan Luas Lingkaran di SDN Tanggul Wetan 02 Kecamatan Tanggul Kabupaten Jember, hlm.166-174.

Susanti, Eva, dkk. (2016). Pengaruh Model Pembelajaran Discovery Learning Terhadap Keterampilan Sains dan Hasil Belajar Siswa Kelas VIII tentang IPA SMP Advent Palu, hlm. 36-41.

Undang - Undang Republik Indonesia No. 20 Tahun 2003 Tentang Sistem Pendidikan Nasional. Jakarta, Depdiknas.

Wicaksono,dkk. (2015). Teori Pembelajaran Bahasa (Suatu Catatan Singkat). Yogyakarta: Garudhawaca.

Wardani, Naniek Sulistya. (2012). Asesmen Pembelajaran SD. Salatiga. Widya Sari Press.hlm 142

Wardani, N. S., Slameto, \& Winanto, A. (2012). Asesmen Pembelajaran SD. Salatiga: Widya Sari Press. 